\title{
Role of Iranian Traditional Needlework in People's Social and Family Life: A Study of Pateh Embroidery in Kerman
}

\author{
Fattaneh Jalal Kamali ${ }^{1}$ \& Batool Hassani Sa'di ${ }^{2}$ \\ ${ }^{1}$ Department of Art \& Architecture, Kerman Branch, Islamic Azad University, Kerman, Iran \\ ${ }^{2}$ PHD student in sociology, Dehaghan Branch ,Islamic Azad University, Dehaghan, Iran \\ Correspondence: Fattaneh Jalal Kamali, Department of Art \& Architecture, Kerman Branch, Islamic Azad \\ University, Kerman, Iran. E-mail: amar.pajoheshco@gmail.com
}

Received: May 27, 2016

Accepted: June 8, 2016

Online Published: December 15, 2016

doi:10.5539/mas.v11n $1 \mathrm{p} 253$

URL: http://dx.doi.org/10.5539/mas.v11n1p253

\begin{abstract}
The aim of this study is to investigate the role of Iranian traditional needlework in people's family and social life with an emphasis on the art of Pateh embroidery. In this article, the history of textile industry, the history of clothes, different sewing styles and how they have been influenced by each other, are studied. According to the "History of Iranian Textile Industry", a book written by Mehdi Beheshtipour, textile industry in Iran dates back to 7000 years ago. Tabari book of history states that this industry goes back to 4000 years ago. Excavations in Shoosh show that burlap weaving, silk weaving and embroidery were forms of art at the time of JamsheedPishdadi. Herodotus says that Xerxes wore embroidered clothes. Marco Polo refers to the art of Kerman's Pateh embroidery in his travelogue. Qajar era is called the renaissance of Iranian needlework. Different styles of needlework have been investigated in previous practical studies with reference to the regionswhere they are common and how they are used. Pateh embroidery is considered as a traditional art in Kerman. This form of needlework has been paid attention to since 1906 from economic, social and cultural perspectives and studied as a profession that can meet people's financial and aesthetic needs.
\end{abstract}

Keywords: needlework, Pateh embroidery, colors, flax, wool cloth

\section{Introduction}

Needlework is known as an art that can have a great effect on individuals' souls, minds and their aesthetic senses by becoming widely spread in social, cultural and family structures. Human beings have long been involved in textile industry and production of cloth. During different ages, they have always tried to transform the industry and add to its variety.One of the artistic styles in this industry is needlework which is the art of adorning the surface layer of simple cloth.

In this style, colorful threads are gracefully woven into textile using very thin needles. Needlework is one of the broadest traditional arts because of its variety. The primary signs of textile industry in Iran belong to an era which dates back to 4000 years before Christ. These signs and clues which have been obtained through excavations in Shoosh, tell us the industry was one of those applied by Ilami people. The statues made of clay demonstrate some decorations on their clothes. Discoveries in areas like Shoosh, Seialk, Gyan hill in Nahavand, Marlik, Hassanlou in Urumiah, Ekbatan or Hamedan, Lorestan, Zivbeh, Gorgan and Bijar, are each indicative of different types of sewing and adornments on clothes. During the period when Median Empire ruled Iran, men and women's clothes had decorations on them made by braiding, filigree work and crocheting. Other documents are related to the needlework which has been created in the years between $550 \mathrm{BC}$ and $330 \mathrm{BC}$ and obtained from Persepolis showing relief needlework on the clothes of courtiers and guards.

Pasirsic discoveries demonstrate signs of needlework created using images of animals, geometrical shapes and mysterious symbolic flowers that are mostly linked to religious aspects of clothing. Some purposes of this study are to pay as much attention as possible to the social aspect of needlework art and its effect on people's lives as an industry that has high capacity for investment and can be considered as an individual's profession. Besides its aesthetic value, this form of art can be a mean to meet financial needs. Bourdieu states in his studies about art that individuals who are interested in practical decorative arts are economically weaker and stand at a lower financial status than those interested in experimental and abstract arts. Besides being used as clothing, 
needlework is applied as cover for home decoration and given to others as gift. Its managed mass production will place it among jobs and trades. As for the limitations of the study, we can refer to the variety of needlework styles, needlework artists' being scattered in different urban and rural areas and that these artists do not possess a particular association or organization which has gone through processes of legalization. Such challenges make it difficult to access the authorities in this field and needlework artists, and collect information about them. Thus, the researcher inevitably adopts library method of research which mostly takes up the study of documents.

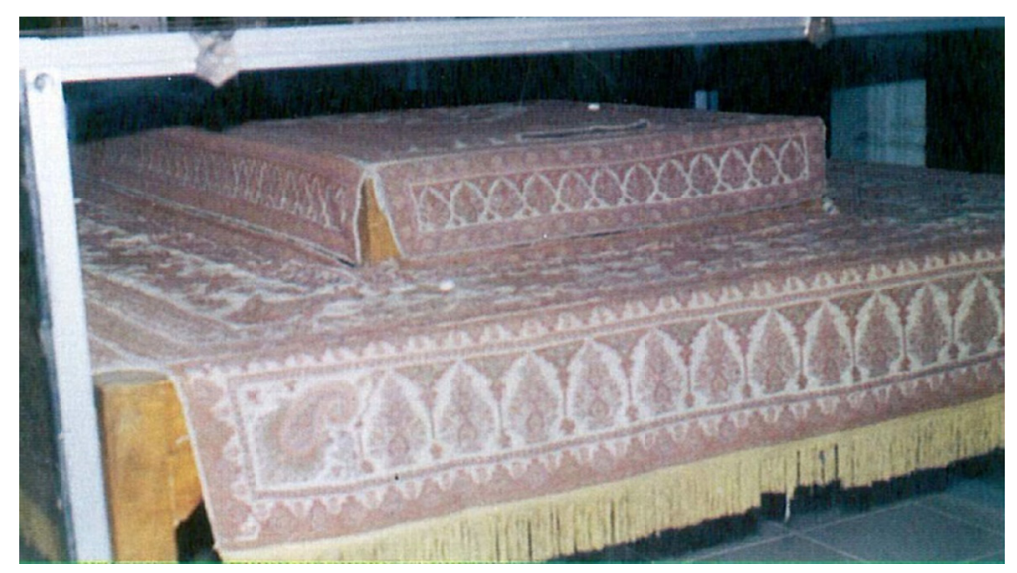

Figure 1. The oldest pateh is spread over Shah Nemat-allahVali's grave in Mahan, Kerman. Source of the picture: (pateh-weaving, Falsafi, Vadiat publications, 2010)

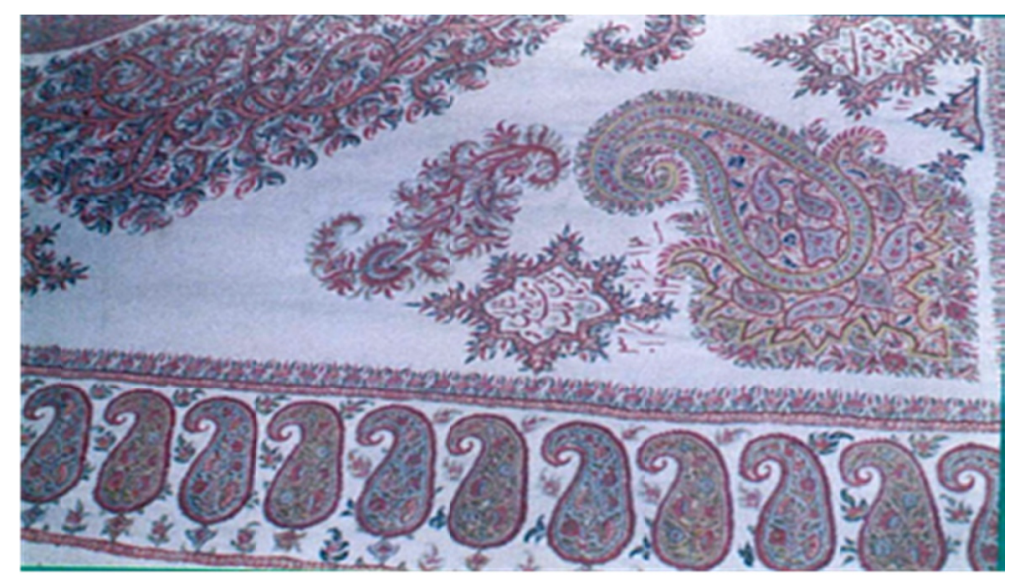

Figure 2. Part of the pateh that is spread over Shah Nemat-allahVali's grave. Source of the picture: (ibid)

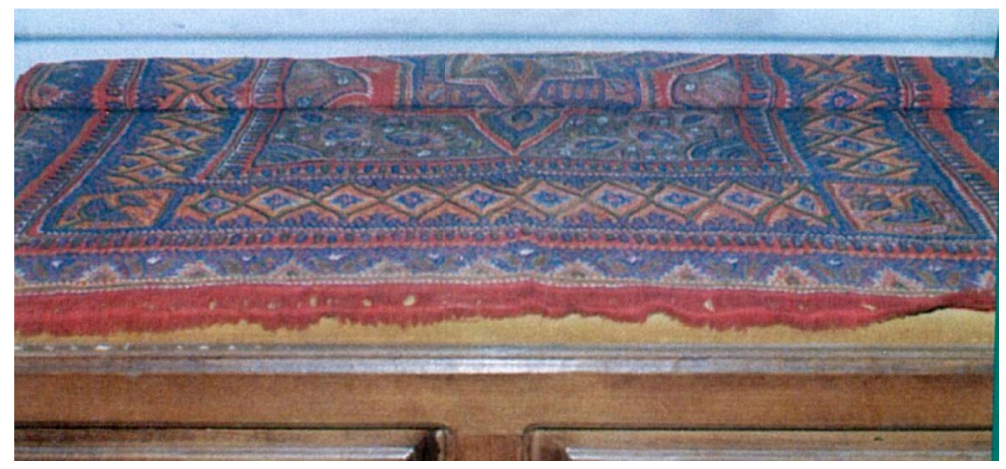

Figure 3. another piece of pateh that is placed in Shah Nemat-allahVali museum in Mahan, Kerman - with the size of $1.5 \times 3 \mathrm{~m}$. Source of the picture: (ibid) 


\section{History of Needlework in Iran}

Needlework is an art in which the surface layer of simple cloth is adorned using colorful threadsand applying needles and clasps. The artists often demonstrate a beautiful integration of tolerance, patience and art bysewing fine stitches on textile (selected works of Saba, 1991: p.1).

Textile industry, history of clothes and different sewing styles are completely interrelated; have direct effects on each other and are directly affected by each other. Due to their changing aesthetic perspectives, human beings have always wanted to transform textile industry and the way they have been adorning their clothes. Consumption of art forms a great part of Bourdieu's sociological studies of art. Regarding love of art, Bourdieu investigates patterns of visitors' presence in French museums. He concludes that there is a relationship between people's artistic taste and their sociocultural class. Individuals who show interest in experimental, abstract and complex art are the people who possess a high economic and cultural status and the individuals interested in practical and decorative art are the ones at lower economic and cultural classes of society (Ramin, Ali, Pishin, pp. 619-620).

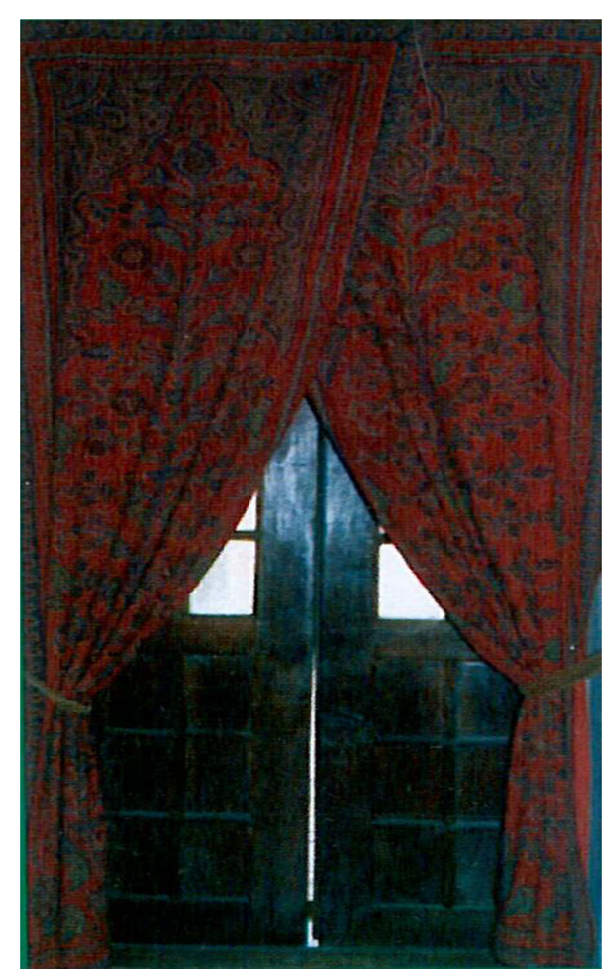

Figure 4. This curtain is more than 100 years old and late Qamar-al-molukAmeri donated it in 1948

It is kept in Shah Nemat-allahVali museum in Mahan, Kerman. Each curtain of this type is sized $3 \times 1.5 \mathrm{~m}$. Source of the picture: (ibid)

Investigating transformation of clothes and their decorations is not only important from a historical and artistic perspective, but also deserves consideration from a sociological and psychological point of view.

In Ibn-Khaldun's Introduction, we read in the chapter on handmade clothes that two professions of weaving and sewing existed among the people of old times. Mehdi Beheshtipour, the author of a book called History of Textile Industry in Iran, says the origin of weaving and sewing dates back to 7000 years ago. In Tabari's Book of History, we see that the author, Mohammad-bin-JarirTabari states that burlap weaving, silk weaving, thread spinning, weaving colorful textile and embroidery have originated at the time of King JamshidPishdadi. The earliest sign of textile that exists in Iran, belongs to $4000 \mathrm{BC}$ which has been obtained through Shoosh excavations. Investigation of the remains of the Persepolis, particularly of the tiles obtained in that area, shows that people's clothes at that time had patterns made by needlework on them. The main patterns were images of animals, geometrical shapes, mysterious figures and symbolic flowers which all had religious significance. Karl Marx, one of the classic thinkers in the field of sociology of art takes up a pattern of superstructure and infrastructure in his analyses. According to Marx, economic realities are the root of all ideologies and art is one of those ideologies (Rafael Max, three studies in sociology of art, Masoumbeigi, Agah, 2000, p. 148). Therefore, 
economic realities can be the origin of and the infrastructure for many ideologies including art. Thus, when economic conditions and modes of production transform, the artistic society will also change considerably. Herodotus writes in his book that Kings' wives, especially King Xerxes's wife wove and sew kings' clothes themselves and applied their needlework artistry in creating them. Textiles discovered in Pasiric show signs of needlework such as braid sewing, embroidery in filigree work, purl sewing, crocheting, one tenth knitting, braiding with precious stones and pearl, spangling and bejeweling; forms of art which adorned clothes and textile of that period of history three to four thousand years before Christ. During the five centuries that Seleucid and Parthian dynasties governed Iran about 3000 years before Christ, the art of needlework has also been considered as an important form of art. In this article, the meaning of needlework as an art is investigated in different eras of Iranian history. In his book entitled "A Review of Needlework as an Art in the History of Iran", Theophilaket, the famous historian of the seventh century describes Hormoz IV's (a king of the Sassanid dynasty) clothes: "The kingwore a brocade pair of pants which had been braid sewn and one tenth knitted and cost very much. After the emergence of Islam in Iran, decorating the surface layer of clothes continued in the form of different sewing techniques such as crocheting, galloons weaving, braiding, quilted sewing, clip weaving, multiple weaving, bejeweling, spangling, stonework, pearl glass, silk weaving and embroidery with flower designs. In the Safavid era, the Iranian needlework and embroidery made such a rapid progress that the entrance of Chinese needlework into Iran stopped at that period.Marco Polo writes in his travelogue that Kermani women created very fine embroidery with flower designs. He might have been referring to Pateh embroidery or chain sewing. Sharden, the famous explorer refers to the fine flower embroidery in the Safavid age. In that period, surface embroidery was so important that the people who created them were known as business owners who enjoyed a high socioeconomic status (Mohammad Mehdi bin Mohammad Reza Esfahani, author of the book half of the world in description of Esfahan). The same book states that braid sewers, one-tenth knitters, spangle weavers, coin sewers andfloret embroiders have also had guilds at that time.

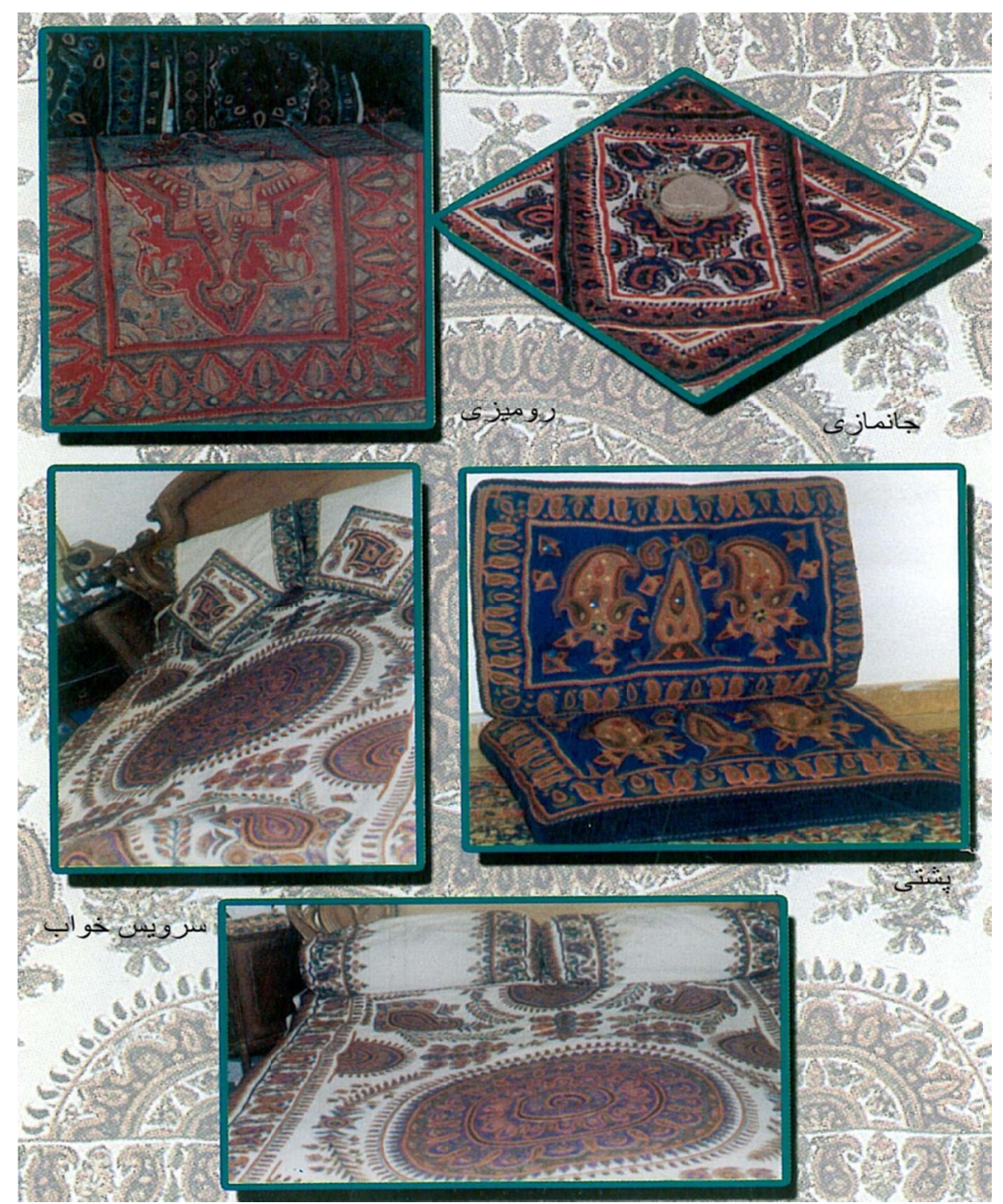

Figure 5. Uses of pateh in everyday life.Source of the picture: (ibid) 
According to Marx, art directly originates from the foundations of economic production. Qajar era is said to be the renaissance of needlework in Iran since it is the time when this art flourishes to a great extent. The glory of needlework in Safavid era can be inferred from the fact that during Afsharieh and Zandieh periods, this art continued following the style applied in Safavid period. The clothes and textile embroidered from 1769 until 1830 (the period when Afsharieh and Zandieh dynasties ruled Iran) are somehow similar to embroidery in Safavid era and it is difficult to distinguish the two from each other (selected works of Saba, 1991, pp. 7-8). During Qajar era, women's dresses were shorter so the decorations made on women's pants increased. Thus, the art of embroidery became a special adornment on pants. Since the use of transparent clothes became widespread in this period, different styles of needlework such as girdle weaving, net clothes sewing, silver sewing, and gilded cloth knitting served the decoration of clothes more than ever before (ibid: 1991, p. 8).

In Qajar era, adornments on pants were less important since the skirts were longer and had more pleats then. However, the shirts and dresses' adornments increased. Cloths used for dresses were often cut in long and circular forms and the margins were decorated by galloons, braids, pearls, glass beads and sweat-bands. The upper part or the Lifeh (the hem in a pair of pajamas or a dress through which tape is drawn) of the dress was often kept up with a leather belt decorated by silk textile and bezel with flower designs (ibid: 1991, p.8).

At this time, Pateh embroidery on colorful cloths using braid threads became popular. Such a form did not exist in any of the previous periods. Pattern sewing, quilted weaving, multiple weaving, cashmere weaving and one tenth knitting reached their summit in this period. In the travelogue written by Samuel Green and Wilber Benjamin, we can read that the best embroidery with flower designs was prepared in Shiraz, Esfahan, Kashan, Yazd, Qaradaq, Tabriz and Rasht, each of which had a variety of designs (ibid: 1991, p. 9).
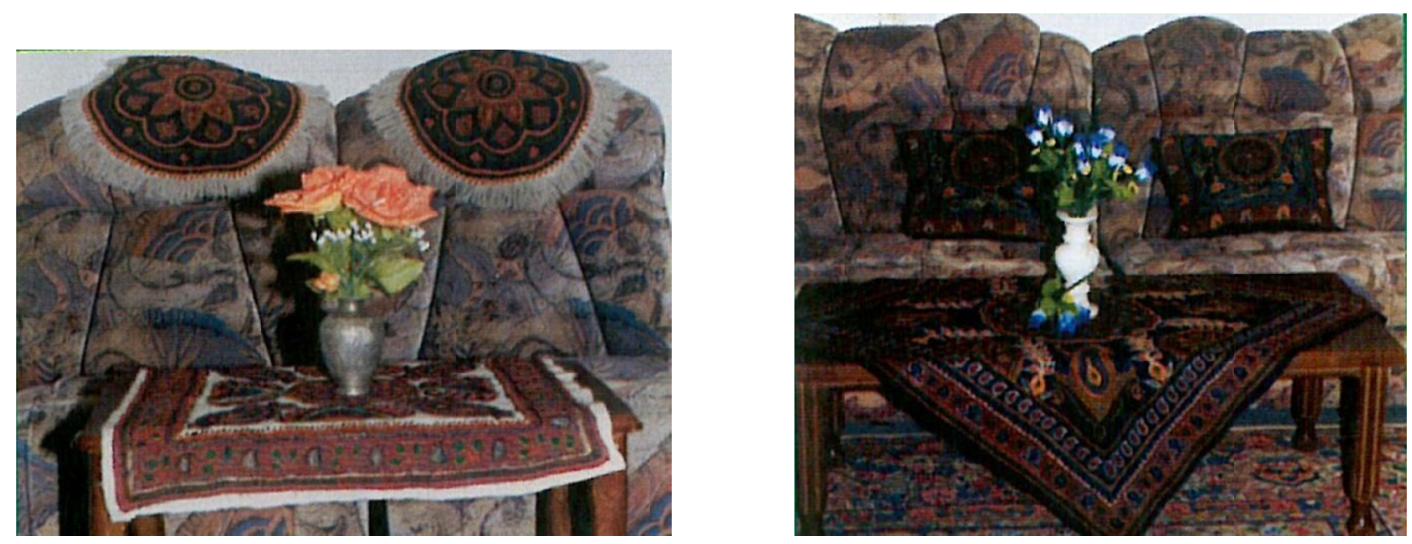

Figures 6. and 7. Pateh as cushion and upholstery (source of the picture: ibid)

\section{Different Types of Traditional Iranian Embroidery}

Iranian embroidery is generally divided into six categories:

1. Needlework that is not recognizable because the main background is filled with many different patterns and in which colorful sewing creates a new background replete with designs and ornaments. Design sewing, crocheting, some kinds of Pateh embroidery or chain sewing, Bukara weaving, Mamaqan weaving, Balooch weaving and Kurdish weaving are some examples of this type.

2. Needlework in which the sewing forms part of the background and the background color remains unchanged. Examples aresilk weaving, braiding and multiple sewing.

3. Needlework that is prepared through a special process of replacing and taking out warps and woofs such as Sakmeh sewing in Esfahan and latticework.

4. Embroidery in which metal threads decorate cloth and give a particular attraction to it. Examples of this kind include braid sewing, one tenth knitting, Naqadeh sewing, purl sewing, embroidery in filigree work and Golab (rose-water) sewing.

5. Needlework in which needles and crochets do not play any role in creating them but metal threads such as silver are passed through the warps and woofs and taken different forms by hand. Two instances of this type are Khoos sewing and Naqadeh weaving.

6. Needlework where it is not only needle and thread that are used to create designs and ornaments but also 
there is a need to other decorative material. Spangling, coin sewing, galloon weaving, pearl knitting, glass beads sewing, stone sewing, sweat-band sewing, bejeweling and cocoon sewing (selected works of Saba: 1991, p. 54).

Table 1. Different production centers and needlework applications in Iran

\begin{tabular}{lll}
\hline Type of needlework & Places & Applications \\
\hline Lasso weaving & Esfahan, Shiraz, 4 ${ }^{\text {th }}$ Hegira century & Prayer rug, bundle, tableau, curtain, clothes \\
Loop weaving & $\begin{array}{l}\text { Esfahan, Kashan, Yazd, Kerman, Rasht, } \\
\text { Hormozgan, Zabol }\end{array}$ & Sugar cloth, tableau, clothes, scarf, cushion \\
Cornice weaving & $\begin{array}{l}\text { Khorasan, Esfahan, Kerman, Zahedan, } \\
\text { Bandar Abbas }\end{array}$ & Prayer rug, clothes, tablecloth, tableau \\
Frieze weaving & Esfahan, Shiraz, Khorasan & Cover for Hajar-al-Aswad (The black stone), mosques' \\
& & walls \\
Pattern weaving & Esfahan, Khorasan, Rasht, Shiraz & Quran's cover, tableau, table cloth, prayer rug \\
Crocheting & Rasht, Esfahan, Mashhad & Mourning flags, prayer rug, cushion \\
Filigree work & Sistan and Baloochestan & Slippers, pants, tableau, shoes, bag \\
Silk weaving & Kafahan, Khorasan & Cuff, curtain, tableau, tablecloth \\
Glass weaving & Kurdistan, Hormozgan, Baloochestan & Money bag, curtain, tablecloth, tableau \\
Cashmere weaving & Esfahan, Yazd, Tehran, Hormozgan & Tablecloth, tableau, curtain, clothes \\
Pearl weaving & Esfahan, Kashan, Yazd, Tehran, Tabriz & Quran's cover, cushion, tableau, tablecloth \\
Pateh embroidery & Kerman, Sirjan, Zarand, Ravar & Quran's cover, tablecloth, curtain, clothes \\
\hline
\end{tabular}

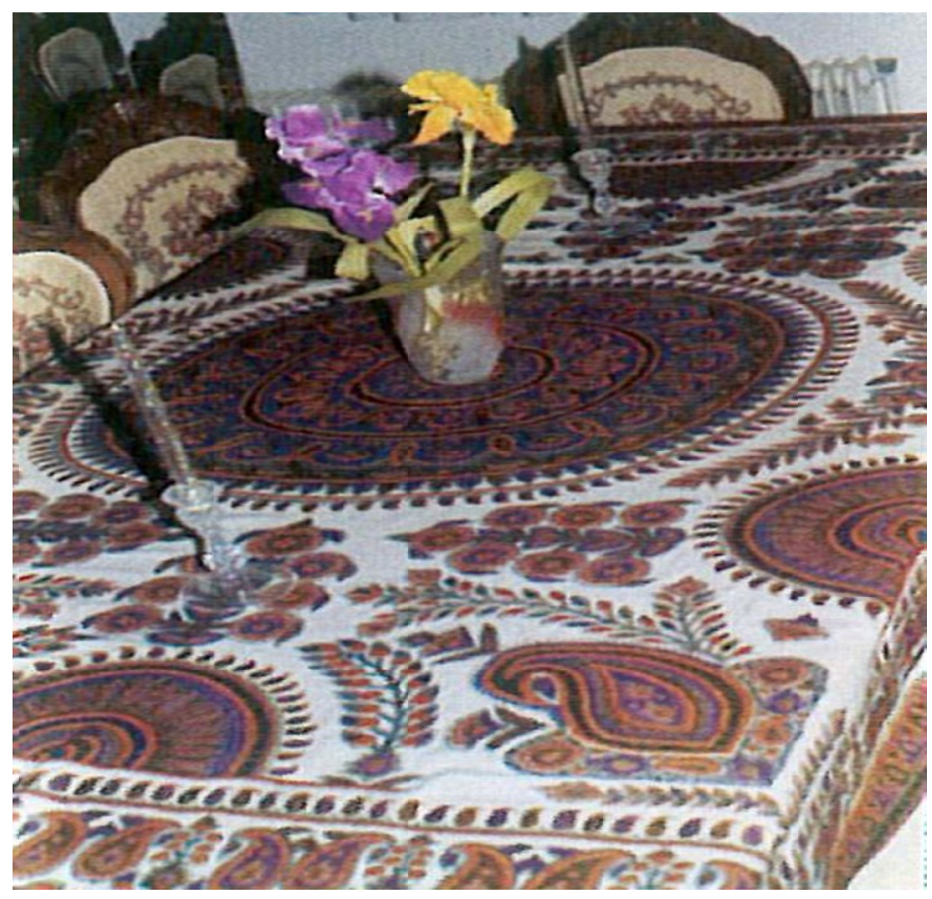

Figure 8. Practical designs of pateh used as tablecloth (source of the picture: ibid)

\section{Pateh Weaving or Chain Sewing as a Popular Art in Kerman}

Moein dictionary defines pateh as smooth wool that is taken from the end part of a goat's hair. This cloth is put on one's shoulders and sashes are made from it (Moein Dictionary, Mohammad Moein, 1, p. 679).

Dehkhoda dictionary provides this definition for pateh: goat's wool, the wool under a goat's hair, the wool at the end of a goat's hair, soft wool that can be combed from the root of a goat's hair and from which sashes, hats, felt, wad, etc. are made (BorhanJahanghiri), fluff (Jahanghiri). (Dehkhoda dictionary, AliakbarDehkhoda - p. 
120).Amid dictionary alsodefines pateh as the soft woolen fluff that grows at the root of a goat's hair from which fine fabrics are made. Pateh weaving is generally referred to as the kind of sewing in which the whole background and sometimes the major part of it is knitted by colorful fluff threads, wool threads or silk threads (Selection of Saba, p. 1991, 111).

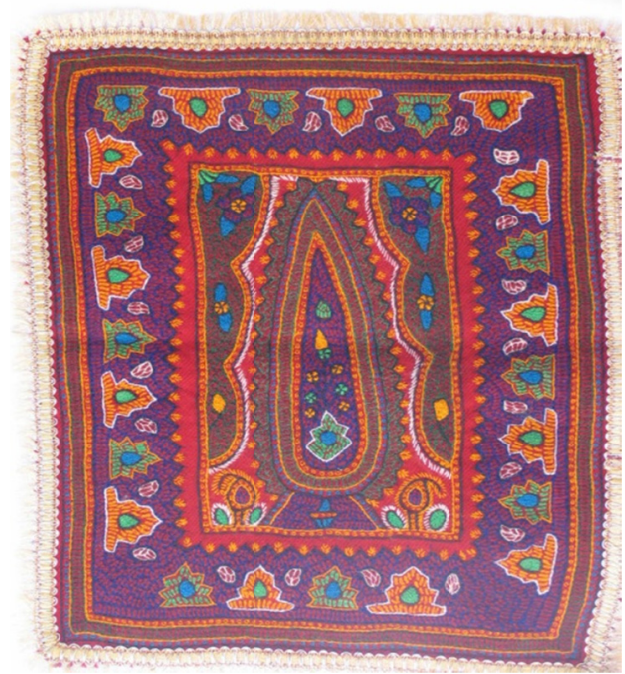

Figure 9. Practical designs of pateh used as prayer rug (source of the picture: authors)

Pateh weaving whose production is common in Kerman, Sirjan and Rafsanjan does not have a definitely specified origin. Each one of its creators relates its emergence to a particular period. Unfortunately, since textileis vulnerable to atmospheric factors, we cannot find any pieces of pateh in national and international museums. So, we cannot certainly trace this form of art to the Safavid period. However, Marvi, who has investigated the topic in different travelogues, proves that this kind of weaving has been completely popular in Kerman during Safavid era, particularly through his study of Sharden's travelogue. According to this researcher, pateh was used for different purposes. Different books of art state that the oldest piece of pateh in the worldbelongs to the year 1906. But the pateh that exists in the museum of decorative arts invalidates such statements.
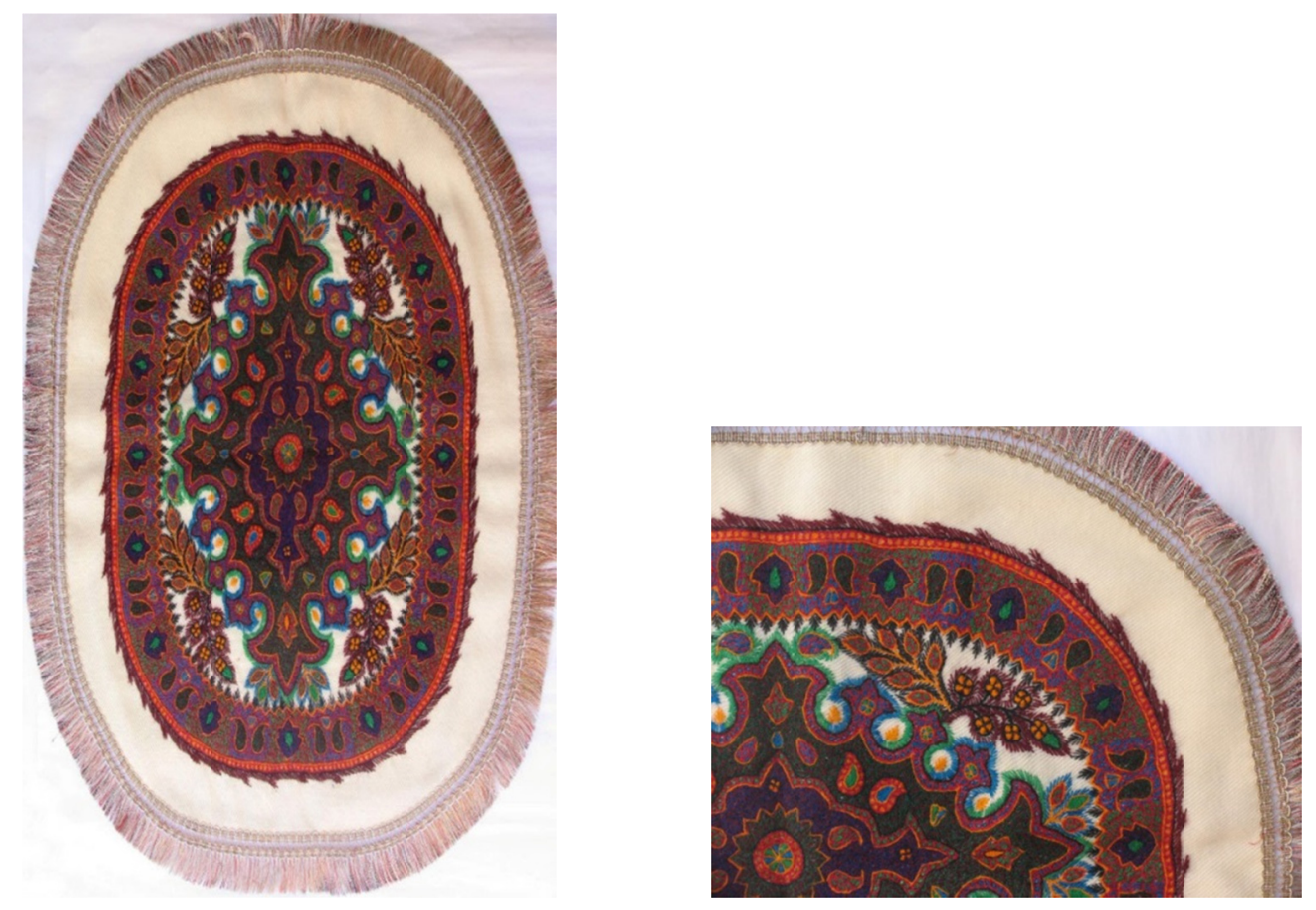

Figures 10. and 11. Practical designs of pateh used as tablecloth (source of the picture: authors) 
The so-called pateh has been created through needlework and its whole background is embroidered by tiny flowers in the shape of tilted chevronsusing colorful silk threads on a cream woolen textile that belongs to the $12^{\text {th }}$ century Hegira. The margins of this pateh have been decorated by a paisley pattern. Another piece of pateh that is of historical significance is the bundle embroidered and chain sewn by Faraj-allahKermani who is a master of this art. He has been able to demonstrates this art in the best way possible. This work of art has a date on it that shows it belongs to the year 1280 Hegira. (ibid: 1991, p. 111).

Yet another unique example of this kind of weaving is the cloth that is spread over Shah Nemat-allahVali in Mahan, Kerman. Much artistic work has been carried out to create this cloth and it is said to be woven in 1285 Hegira year.

This pateh which is the result of 16 female Kermanipateh-weavers' non-stop work in two years, is sewn on a cloth with the length of $355 \mathrm{~cm}$ and width of $210 \mathrm{~cm}$ and is a very brilliant instance of Kermani women's gift and artistry. Pateh-weaving is a type of Iranian surface embroidery in which the whole surface of a cloth is covered by colorful stitches. The artists, who are mostly housewives and their daughters, create designs on a piece of thick wool cloth called Areez (which means wide); all the designs are formed through mental plans which exist only in the artists' minds. (ibid: 1991, p. 111).

Areez which was also used to sew dresses, women's jackets and overcoats in the past is a handmadecloth created by hand looms in white, red, yellow and green colors (selected works of Saba, Saba publications: 1991, p. 111).

Rees which is commonly used by pateh-weavers in brown, black, light green, dark green, yellow, orange, red, dark blue, crimson and some other colors is a kind of handmade or machine-made wool thread whose consumption rate is different depending on design type and the thread's thickness. However, embroidery of a one-meter pateh needs about 375 to 400 grams of thread on average. In the past, silk threads and braids were used for pateh weaving besides Rees. The pieces that have remained from those times are signs of transformation and change in this art (ibid: 1991, p. 112).

Leo Tolstoy considers art as a means of human beings' communication with each other and thinks that it would help mankind improve and progress towards perfection (Leo Tolstoy: What is art? Translated by KavehDehgan, Tehran 1985, p. 170).

The special grace and beauty of pateh comes from traditional and original Iranian designs and shapes such as paisley or life tree. This design is one of the commonest Iranian images that have been popular in all kinds of hand-woven material and in different types of sewing. There have always been different views about the origin of designs on pateh and art experts have expressed different and often contradictory statements about their root and origin. Some scholars consider pateh as a symbolic manifestation of fire in Zoroastrian fire-temples and some see it as the allegory of almonds and pears. Some have recently come to the conclusion that these designs are visualizations of an Indian plant and thus have stated that paisley has entered Iran from India and transformed into different shapes and forms. There is a lot of historical evidence available that none of these hypotheses is true and it is almost certain that pateh is originally the image of a cedar tree whose branches have been bent down by the wind and contrary to the common belief, it has gone to India from Iran. (selected works of Saba, Saba publications, 1991, p. 113).

Because of their love of inventing different types of complex artistic designs, Iranian people have created different shapes of bushes and have given them particular names such as BotehMiri (little pine), BotehTermeh (medium pine), BotehKherqei (geat pine), BotehBadami (Almond-like pine), paisley, antler bush, cashmere bush, Band-e-Sarabandi, Esfahan calico bush, Kurdistani bush or eight-bushes, Mirshekasteh bush, Bergamot Lachak bush, paired bush, twin paisley, triple paisley, mother and child paisley, war and peace bush, Sanandaji bush, Afshari bush, armband bush, etc.

Other designs that are used in pateh-weaving and chain-sewing are bergamot ivy, little cedar; cedar-shaped, animal figures especially birds, geometrical shapes, sun-like, bergamot lachak, Afshan (small branch), different kinds of Eslimi (arabesque), Khataee Shah Abbassi flowers, pomegranate, cluster designs and Chaharbeseh, marginal, etc.

Pateh-weavers select their favorite designs from famous Kermani artists and designers such as master Mohsen Khan, a painter in the $13^{\text {th }}$ century Hegira, Hassan bin Mohsen Khan, a painter who died in the year 1319 solar Hegira year, Zaman Khan Mirhosseini, Hassan Khan's pupil who died in 1304 solar Hegira, Sheikh RamezanMirSarjani died in 1322 solar Hegira, the master of Kazemthe painter, Ahmad Khan, Ahmad Alikhan and Karbalaee Akbar (ibid: 137: 114).

According to Michel Foucault, works of art can reflect all the intellectual and cultural context of their time and 
human being can be defined again with the help of artistic concepts. In his opinion,the intellectual conditions of every age can be investigated through artistic creations of that age (Ramin, Ali, Pishin, p. 583).

Pateh weaving was an art in which men worked as well and trained novice artists. One of the well-known male masters of this art in $13^{\text {th }}$ century (lunar Hegira) was Faraj-allahKermani (who used machinery to weave sashes) and master MirAliKermani. The people of high classes in the society in Kerman particularly Kermani aristocrats and military officials used pateh as their clothes and for decorating their houses. In winter, pateh was used to sew wool curtains which gave beauty to the people's houses and at the same time created pleasant warmth in the rooms. In addition, pateh with linen was used as the cloth to be spread over a heating table in order to increase its warming effect. Nowadays, that cloth has taken the form of a bed sheet with a smaller size. People also placed Pateh cushions under their hands. Such cushions were beautiful and warm. Pateh bundle was one of the bathing utensils at that time. Bathroom towels were put in the pateh bundle which is nowadays like a tablecloth. This form of pateh whose size was $1 \times 1.5 \mathrm{~m}$, was spread in the bathrooms' dressing space. These bundles are now used as tablecloths. When the bundle was spread, they placed a soft sheet on it so that the cold of the floor would not reach their feet. Since the bundle was made of wool, it contributed to the warmth in that place. Courtiers and aristocrats used winter clothes made of pateh. It is quoted in the history of Kerman that King Nadir wore clothes made of pateh and for this reason such clothes were called Naderipateh. In those days, women wove their winter jackets and pants with clothes containing pateh embroidery. Aristocrats sew their clothes first and then got them embroidered by pateh. At that time, pateh-weaving was a profitable art (Falsafi, Najmeh 2010, pp. 2-3). One type of pateh which demonstrates a religious aspect is an old piece woven in eight years by 16 Kermani women, beginning in the year 1294 lunar Hegira year. The names of the 14 innocent leaders (according to Shiite religion) are sewn in the flowers at the top of the pateh. Late Shahab-al-molk donated this piece of art to Shah Nemat-allahVali's museum in Mahan, Kerman, in Qajar period. This pateh which is $355 \mathrm{~cm}$ long and $210 \mathrm{~cm}$ wide has been kept there since then (ibid: 3 ).

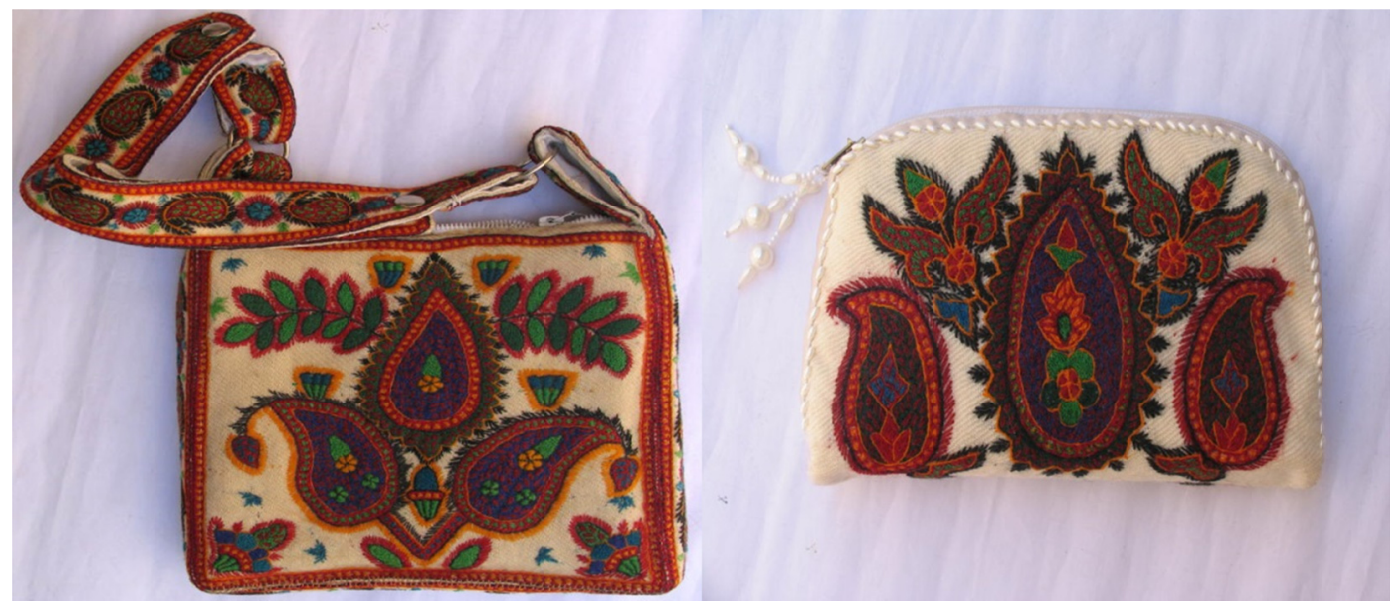

Figure 12. and 13. Practical designs of pateh used as shoulder bag and handbag (source of the picture: ibid)

The designs on pateh are rooted in Kermani people's beliefs. Designs which show the sun, half of the sun, sun-shaped figures and the like are related to the religious ideas of a minority group of Zoroastrians living in Kerman. Zoroastrians believe that prophet Zoroaster has brought a branch of cedar from heaven to the earth and consider the sun as the origin of life and symbolically use their images in the art of pateh-weaving (Buteh (bush) in the culture of Kermani people is accompanied by originality and nobility, and the philosophy behind creating different forms of it in Kermani pate embroidery is that this ancient art is originally from Kerman). (ibid: p.5)

\section{Pateh-Weavers, Common Places, Its Applications}

Currently, pateh-weaving in Kerman is exclusively carried out by women. Housewives allocate their free time to this art and encourage their daughters to learn pateh-embroidery. Pateh works created this way are often used in houses and forms part of girls' paraphernalia. If pateh is woven without taking the market for selling into account, it would have a better quality (ibid: p. 19).

According to the investigations carried out in 1981, the whole population of pateh-weavers in Kerman province was estimated to be 500 who were busy practicing the art scattered in the cities of Kerman, Sirjan, Zarand, Ravar, Bardsir, Zangiabad, Ekhtiarabad, Hojjatabad and villages around Zarand. Based on the investigation in 2004, the total number of pateh-weavers in Kerman province was estimated to be about 20000 people. The income of each 
person per month was approximately 150000 tomans. The products often created arecoasters, cushions, backrests, needle worked curtains,bundles, bed sheets, tablecloth, Quran's cover, paper tissue boxes, bags, shoes, prayer rugs, dresses and women's pants, tableaus, belts, etc. (Selected works of Saba: 1991 p. 117) and (NajmehFalsafi: 2010 p. 7)

The formal statistics issued by handicraft industries' organization, states that the number of pateh-weavers by the year 2004 was 30000 individuals (statistics center at Kerman province's industries' organization.)

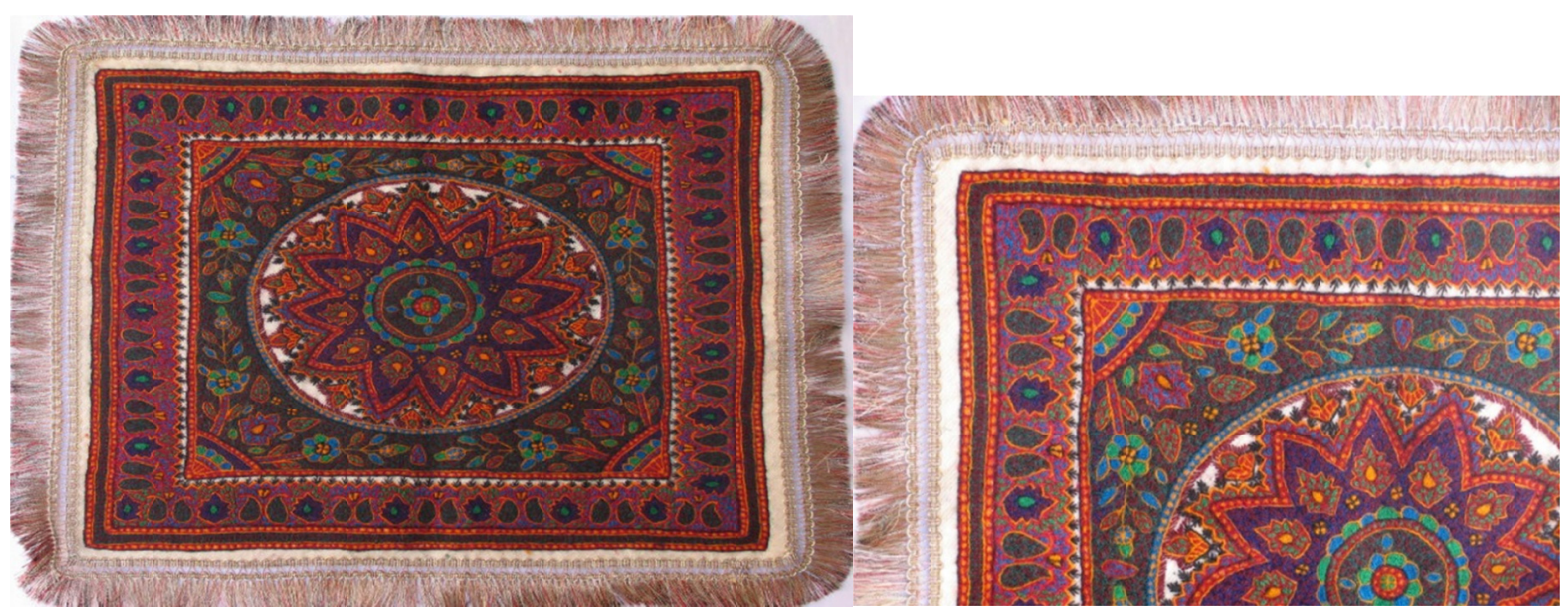

Figures 14. and 15. practical designs of pateh used as tablecloth (source of the picture: authors)

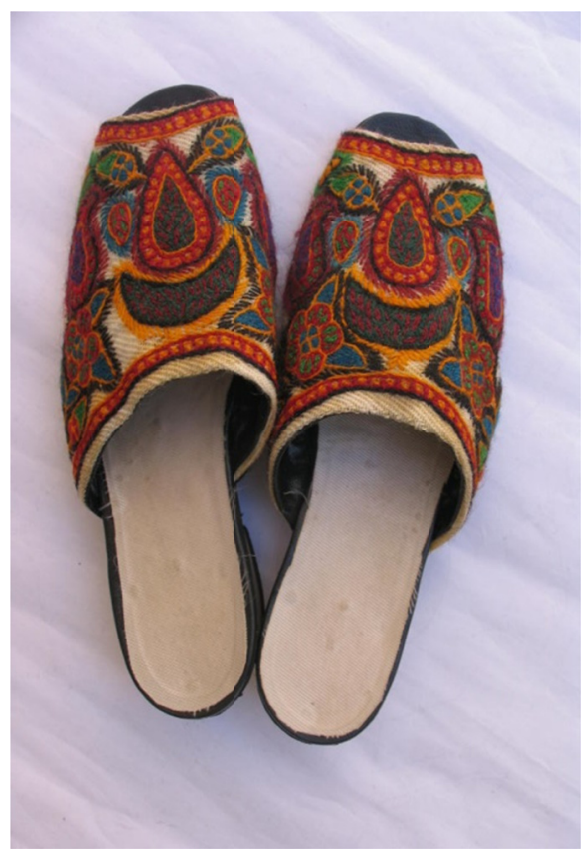

Figure 16. Practical designs ofpateh used as sleepers (authors)

\section{Conclusion}

The results of this study are indicative of overt and covert dimensions and aspects related to the effect of traditional Iranian needlework, particularly pateh-weaving in Kerman on social, family and cultural life of the people in the society. Different styles of needlework as a valuable art dominate individuals' aesthetic, cultural and social lives and transform their insight. Pateh can go beyond a mere art: it can meet individuals' basic needs or in Durkheim's words, create solidarity in the society through division of social labor. According to Michel 
Foucault, works of art can reflect all the intellectual and cultural spirit of their time. Through artistic concepts, we can define human being in a new way and investigate the intellectual context of different ages. In none of the eras in the history of embroidery in Iran, economic aspect of this art has been neglected. Whenever this form of art has flourished, we have seen the effect of economic motives in such a way that some kinds of needlework in the past have become obsolete in Iran since they had not been profitable.

\section{References}

Falsafi, N. (2010). pateh-weaving in Kerman - Kerman, Vadiat publications.

Masoumbeigi, A. (2000). Three studies in art sociology, Agah.

Omidi, N. (2003). A study of clothes and traditional arts in Khorasan, Mashhad: Behnashr company.

Ramin, A. (2008). Principles of art sociology, Tehran, Nei.

Saba, E. S. (1991). A view of the Iranian traditional needlework trend- Tehran, Arian printer. Statistics' center at Kerman province's handicrafts organization.

Tolstoy, L. (1985). What is art?, translated by Dehgan, Kaveh, Tehran, Amirkabir.

\section{Copyrights}

Copyright for this article is retained by the author(s), with first publication rights granted to the journal.

This is an open-access article distributed under the terms and conditions of the Creative Commons Attribution license (http://creativecommons.org/licenses/by/4.0/). 